\title{
Zoonotic infectious diseases and maritime seaport: areas of concern
}

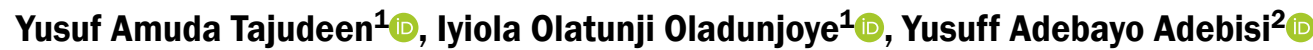

${ }^{1}$ Department of Microbiology, Faculty of Life Sciences, University of Ilorin, Nigeria

${ }^{2}$ Faculty of Pharmacy, University of Ibadan, Nigeria

Over the millennia, several pandemics including bubonic plague and Spanish flu have been reportedly spread aboard ships including the recent coronavirus disease 2019 (COVID-19) [1, 2]. These diseases are known to be zoonotic in origin. This is because of their ability to circulate initially in other vertebrate animals before circulating in the human population as a result of cross-species transmission of pathogenic microbes during human-animal contact. However, zoonosis is a public health threat that accounts for about $60 \%$ of emerging infectious diseases across the globe, and its ease on global transmission is facilitated by the physical interconnectedness of our world through efficient intercontinental transport chains, especially via the maritime - being the most demanding transport route $[3,4]$. The rising challenges of zoonotic infectious diseases being linked with maritime seaport; particularly on factors including ballast water, travel and trade, and seafarers are important areas of public health concern. This is to increase the level of preparedness and response to any future outbreaks of pandemic potential that may stem from the maritime seaport.

To maintain stability on the sea, all ships carry ballast water - this untreated water, which is being discharged from one part of the world to the other may contain aquatic invasive species including the green crab that harbours zoonotic pathogens (such as Vibrio cholerae) of public health significance [5]. Annually, an estimated 3-5 billion tons of ballast water containing 7000-10,000 aquatic invasive species are being carried by ship from one part of the world to the other [5]. The cholera epidemic in Peru in 1991 has been linked with untreated ballast water from Bangladesh [6]. The outbreak later spread to Latin America in 1994 causing an estimate of about 10,000 deaths.

Advancement in technology has made available different kinds of cruise ships which may be used for efficient transport of a large number of passengers and heavy cargo including trafficking of wildlife across the world, and this reflected on the constant high demands for maritime transports for international travel and trade - which are associated with globalisation. According to United Nations Conference on Trade and Development (UNCTAD) in 2020, maritime transport accounts for $~ 80 \%$ of international trade [4]. Cruise ships bring large numbers of passengers from many countries, including asymptomatic carriers, on board - as in the case of the 1918/1919 influenza pandemic [7]. This may lead to both direct person-to-person transmission and indirect transmission through contaminated surfaces and in turn, increases the influx of diseases to new countries - as happened with COVID-19 [2]. Increased demand for wild animals and their parts has led to the trafficking of wildlife. Wild animals including pangolin and donkeys are threatened due to the constant demand for their scale and skin respectively in traditional Chinese medicine, from 2000 to 2019 , about 895,000 pangolins are traded across the world [8-10]. These animals, usually transported via the ocean and declared as cargo, are known to harbour various zoonotic pathogens including viral zoonosis which can spill over to humans during human-animal contact along the trade chain, thus contributing to zoonotic infectious diseases outbreaks.

The risk of spread of zoonosis by seafarers is facilitated by their vulnerability to various climatic changes favouring the spread of infectious diseases due to the nature of their on-board work. Increased visits to numbers of ports across the world exposed them to various outbreaks including epidemics and pandemics that may be transmitted to passengers and other crew members on board as well as to other parts of the world. It is noted that seafarers are usually vaccinated against internationally notifiable diseases

Dr. Yusuf Amuda Tajudeen, Department of Microbiology, Faculty of Life Sciences, University of Ilorin, Ilorin, Nigeria, e-mail: tajudeenamudayusuf@gmail.com

This article is available in open access under Creative Common Attribution-Non-Commercial-No Derivatives 4.0 International (CC BY-NC-ND 4.0) license, allowing to download articles and share them with others as long as they credit the authors and the publisher, but without permission to change them in any way or use them commercially. 
including plague and cholera. However, seafarers are more vulnerable to new infectious diseases outbreaks in docks, ports, and countries where they visit as a result of the constant evolution of novel pathogenic zoonoses.

The global transmission of zoonotic infectious diseases through the maritime seaport is an area of public health concern. To address this public health threat, maritime legal institutions such as International Maritime Organization should work with public health institutions like Global Outbreak Alert and Response Network to curb the global spread of zoonotic infectious diseases tied to the maritime seaport.

\section{Conflict of interest: None declared}

\section{REFERENCES}

1. The Inside History Newsletter. Pandemics That Changed History. . https://www.history.com/topics/middle-ages/pandemics-timeline (August 04, 2021)

2. The Guardian News and Media limited. Australia News: More than 400 coronavirus cases-10\% of Australia's total-are from Ruby Princess cruise ship. https://www.theguardian.com/australia-news/2020/mar/31/more-than-400-coronavirus-cases-australia-total-ruby-princess-cruise-ship (August 04, 2021).

3. Tajudeen $\mathrm{Y}$, Oladunjoye I, Adebayo A, et al. The need to adopt planetary health approach in understanding the potential influence of climate change and biodiversity loss on zoonotic diseases outbreaks. Public Health in Practice. 2021; 2: 100095, doi: 10.1016/j. puhip.2021.100095.

4. United Nations Conference on Trade and Development. UNCTAD Review of Maritime Transport. https://unctad.org/topic/transport-and-trade-logistics/review-of-maritime-transport (August 04, 2021).

5. Satir T. Ship'S Ballast Water And Marine Pollution. Integration of Information for Environmental Security. In: Coskun HG, Cigizoglu HK, Maktav MD (eds) integration of information for Environmental Security. NATO Science for Peace and Security Series C: Environmental Security. Springer, Dordrecht. 2008: 453-463, doi: 10.1007/9781-4020-6575-0_30.

6. Organisation for Economic Co-operation and Development. The Competitiveness of Global Port-Cities, OECD Publishing, Paris. https://doi.org/10.1787/9789264205277-en (August 04, 2021).

7. Summers JA. Pandemic influenza outbreak on a troop ship-diary of a soldier in 1918. Emerg Infect Dis. 2012; 18(11): 1900-1903, doi: 10.3201/eid1811.AD1811, indexed in Pubmed: 23092739.

8. African donkeys threatened with extinction: export boom to China. http://www.asianews.it/news-en/African-donkeys-threatened-with-extinction:-export-boom-to-China-44690.html (August 04, 2021).

9. Wang Y, Turvey S, Leader Williams N. Knowledge and attitudes about the use of pangolin scale products in Traditional Chinese Medicine (TCM) within China. People and Nature. 2020; 2(4): 903-912, doi: 10.1002/pan3.10150.

10. PHYS.ORG. Nearly 900,000 pangolins trafficked worldwide: watchdog. . https://phys.org/news/2020-02-pangolins-trafficked-southeast-asia- watchdog.amp (August 04, 2021). 